\title{
DAMPAK PANDEMI COVID-19 TERHADAP MANAJEMEN DAN STRATEGI PEMASARAN SAYUR ORGANIK \\ (Studi Kasus di Kelompok Tani Tranggulasi Desa Batur, Kabupaten Semarang)
}

\author{
THE IMPACT OF COVID-19 PANDEMIC ON MANAGEMENT AND \\ MARKETING STRATEGY OF ORGANIC VEGETABLES \\ (Case Study in the Tranggulasi Farmer Group in Batur Village, Semarang Regency)
}

\author{
ILLENE NAOMI NUGROHO ${ }^{1 *}$, YULIAWATI ${ }^{2}$ \\ ${ }^{1}$ Program Studi Agribisnis, Fakultas Pertanian dan Bisnis, \\ Universitas Kristen Satya Wacana \\ ${ }^{2}$ Staff Pengajar Program Studi Agribisnis, Fakultas Pertanian dan Bisnis, \\ Universitas Kristen Satya Wacana, Salatiga \\ *E-mail corresponding: 522017003@student.uksw.edu
}

\begin{abstract}
ABSTRAK
Masyarakat zaman sekarang mulai memperhatikan produk yang dikonsumsi seperti sayur organik. Munculnya covid-19 berdampak pada penjualan sayur organik. Salah satu pelaku usaha yang mengalami dampak covid-19 adalah kelompok tani Tranggulasi. Tranggulasi bergerak sebagai produsen dan pemasok sayur organik di beberapa kota. Munculnya Covid-19 berdampak pada penjualan sayur organik. Tujuan penelitian ini yaitu mengkaji dampak pandemi Covid-19 terhadap manajemen dan strategi pemasaran sayuran organik di Tranggulasi. Metode penelitian yang digunakan adalah analisis deskriptif, bauran pemasaran (4P), dan Analytical Hierarchy Process (AHP). Berdasarkan hasil penelitian, dampak Covid-19 terhadap manajemen yaitu kesulitan pendistribusian sayur organik, penjualan produk yang dinamis, serta memaksimalkan penjualan dengan media sosial. Berdasarkan hasil analisis AHP pada tingkatan faktor, produk menjadi fokus utama dengan bobot 0,29. Tingkatan aktor, sekretaris dengan bobot 0,44 . Prioritas tujuan dalam strategi pemasaran yaitu meningkatkan mutu dan kualitas dengan bobot 0,29 . Pada level alternatif, menetapkan standar kualitas produk menjadi prioritas dengan bobot 0,37 .
\end{abstract}

Kata kunci: Analytical Hierarchy Process (AHP), bauran pemasaran, manajemen strategis, sayur organik, Tranggulasi

\begin{abstract}
Today's a lot of people are starting to pay attention to consumed products such as organic vegetables. The emergence of covid-19 has an impact on the sale of organic vegetables. One of the business actors who have experienced the impact of Covid-19 is the Tranggulasi farmer group. Tranggulasi is engaged as a producer and supplier of organic vegetables in several cities. The emergence of Covid-19 had an impact on the sale of organic vegetables. The purpose of this study is to examine the impact of the Covid19 pandemic on the management and marketing strategies of organic vegetables in Tranggulasi. The research method used is descriptive analysis, marketing mix (4P), and Analytical Hierarchy Process (AHP). Based on the research results, the impact of Covid-19 on management is the difficulty of distributing organic vegetables, selling dynamic products, and maximizing sales with social media. Based on the results of AHP analysis at the factor level, the product is the main focus with a weight of 0.29. Level of actors, secretaries with a weight of 0.44. The priority objectives in the marketing strategy are improving quality and quality with a weight of 0.29. At the alternative level, setting product quality standards is a priority with a weight of 0.37 .
\end{abstract}

Keywords: Analytical Hierarchy Process (AHP), marketing mix, strategic management, organic vegetables, Tranggulas 


\section{PENDAHULUAN}

Seiring berkembangnya zaman, masyarakat mulai memperhatikan akan produk-produk yang dikonsumsi. Pandangan masyarakat akan kebutuhan produk pertanian pun mulai berubah. Masyarakat mulai memilih produk yang dapat menunjang kesehatan seperti produk organik. Menurut riset Organic Trade Association, penjualan produk organik mengalami peningkatan 5,9\% pada tahun 2018 hingga $\$ 47,9$ juta. Penjualan produk organik diprediksi akan terus meningkat hingga $\$ 60$ juta pada tahun 2022. Berdasarkan Statistik Pertanian Organik Indonesia (SPOI) 2016 jumlah permintaan konsumen terhadap produk organik meningkat 54 persen dibandingkan tahun sebelumnya.

Sejak ditetapkannya wabah virus Corona-19 (Covid-19) sebagai pandemi oleh WHO pada tanggal 11 Maret 2020, Indonesia sebagai salah satu negara yang terkena wabah virus tersebut merasakan dampaknya, terutama terhadap perekonomian. Tingkat penurunan permintaan di pasar dapat mencapai 50\% akibat berkurangnya aktivitas masyarakat untuk berbelanja ke pasar (Abdaloh, 2020). Jika permintaan sayuran di pasar mengalami penurunan, berbeda dengan permintaan sayuran organik. Selama masa pandemi berlangsung, penjualan sayur organik di Indonesia meningkat hingga 50\% (Mariana, 2020).

Kelompok Tani Tranggulasi yang berada di Desa Batur, Kecamatan Getasan, Kabupaten Semarang adalah salah satu produsen dan pemasok sayuran organik yang mengalami dampak Covid-19. Selama masa pandemi Covid-19 adanya penerapan pembatasan akses keluar masuk menjadi terbatas menyebabkan Tranggulasi harus mengubah perencanaan agar penjualan produk - produk pertaniannya tetap dapat tersalurkan dengan baik dan juga pendapatan tetap stabil.

Pandemi Covid-19 secara langsung berdampak pada penurunan/peningkatan permintaan sayuran organik di satu sisi tidak selalu dapat dipenuhi Kelompok Tani Tranggulasi karena adanya keterbatasan kapasitas produksi dan proses produksi (budidaya) sayuran membutuhkan waktu, sedangkan di sisi lain perubahan tersebut harus selalu konsisten misi Kelompok Tani Tranggulasi yang bertekad membangun hubungan kerjasama kemitraan untuk pemasaran hasil sayuran organik. Ketiga komponen ini merupakan bagian dari manajemen, sehingga dapat dikatakan Pandemi Covid-19 berdampak pada manajemen. Menurut Putri manajemen pemasaran adalah usaha yang 
dilakukan dalam merencanakan, mengimplementasikan (terdiri dari kegiatan mengorganisir, mengarahkan, mengkoordinir) serta mengawasi atau mengendalikan kegiatan pemasaran agar tujuan dapat tercapai secara efisien dan efektif.

Selama masa pandemi ini, tahapan yang harus dilakukan Kelompok Tani Tranggulasi dalam menghadapi Pandemi Covid-19 adalah melakukan identifikasi dampak pandemi terhadap manajemen. Tahapan selanjutnya adalah mengidentifikasi dampak Covid-19 terhadap tujuan Kelompok Tani Tranggulasi. Output akhirnya adalah Kelompok Tani Tranggulasi mampu menyusun suatu strategi bauran pemasaran meliputi strategi produk, strategi harga, strategi promosi, dan strategi distribusi.

Penelitian ini merupakan pengembangan dari penelitian yang pernah dilakukan oleh Kihi (2014), namun dengan kondisi yang berbeda karena dikaitkan dengan masa Pandemi Covid-19 dan dalam adaptasi kebiasaan baru yang belum pernah diteliti yaitu mengkaji bagaimana dampak Pandemi Covid-19 terhadap manajemen di Kelompok Tani Tranggulasi dan strategi pemasaran sayuran organik yang diterapkan oleh Kelompok Tani Tranggulasi serta rancangan prioritas alternatif strategi pemasaran yang sesuai dan efektif diterapkan dalam adaptasi kebiasaan baru dengan analisis AHP.

\section{METODE PENELITIAN}

Penelitian ini dilaksanakan di Kelompok Tani Tranggulasi yang terletak di Desa Batur, Kabupaten Semarang, Jawa Tengah pada bulan Juli hingga Agustus 2020. Penelitian ini menggunakan metode kualitatif deskriptif. Data yang dikumpulkan dalam penelitian ini meliputi data primer dan data sekunder. Unit analisis dalam penelitian ini adalah ketua, sekretaris, dan dua anggota kelompok Tani Tranggulasi. Unit amatan dalam tulisan ini meliputi bentuk-bentuk dalam bauran pemasaran (marketing mix) 4P: Product (produk), Price (harga), Place (distribusi), dan Promotion (promosi). Teknik pengumpulan data yang digunakan dalam penelitian ini adalah observasi, wawancara, studi dokumentasi, dan kuesioner AHP.

Berdasarkan pengisian hasil kuesioner oleh para key informant, maka dilakukan tahap konsistensi logis dengan beberapa langkah:
a. Menentukan vector jumlah tertimbang
b. Menghitung vector consistency
c. Menghitung rata-rata vector consistency:

$$
\alpha \max =\frac{\sum x}{n}
$$

d. Menghitung Consistencty Index (CI): 


$$
\mathrm{CI}=\frac{\lambda \max -n}{n-1}
$$

e. Menghitung Consistency Ratio (CR):

$$
\mathrm{CR}=\frac{C I}{R I}
$$

f. Random Index (RI)

AHP mengukur konsistensi menyeluruh dari berbagai pertimbangan melalui rasio konsistensi. Nilai konsistensi harus $10 \%$ atau kurang, jika ini lebih dari $10 \%$, pertimbangan itu mungkin agak acak dan perlu diperbaiki, perhitungan konsistensi didasarkan pada nilai consistency ratio (CR) yang didapat dari perbandingan antara consistency index (CI) dengan random index (RI).

\section{HASIL DAN PEMBAHASAN}

Gambaran Umum Partisipan dan Key Informant

Penelitian ini menggunakan 2 (dua) partisipan dan 2 (dua) key informant dari anggota kelompok tani Tranggulasi. Partisipan tersebut yaitu Pak Harto (bendahara) dan Bu Sri (anggota). Key informant yaitu Pak Pitoyo (ketua) dan Pak Wahab (sekretaris) sekaligus bagian pengadaan barang sayuran organik di Tranggulasi.

\section{Gambaran Umum Kelompok Tani Sayur Organik "Tranggulasi"}

Kelompok tani Tranggulasi merupakan produsen penghasil sayur organik yang sudah berdiri sejak tahun 2000. Organisasi ini terletak di Dusun
Selongisor, Desa Batur, Kecamatan Getasan, Kabupaten Semarang, Jawa Tengah. Para anggota setuju untuk membentuk suatu kelompok tani karena adanya keterbatasan dalam membeli saprodi dan keperluan lainnya. Tranggulasi saat ini beranggotakan 32 petani dengan lahan dan produk organik yang telah disertifikasi oleh lembaga berwenang seperti LSO. Selain itu Tranggulasi sudah menjadi tempat kegiatan P4S (Pusat Pelatihan Petani Pedesaaan Swadaya) sejak tahun 2006.

\section{Komoditas sayuran yang} dibudidayakan oleh kelompok tani tersebut sangat beragam, diantaranya: sawi putih, kubis, kentang, brokoli, tomat, lootus, kacang panjang, labusiam, dan masih banyak lagi. Salah satu produk yang berhasil ekspor yaitu baby buncis ke Singapura dan Malaysia. Produk sayuran lainnya dikirimkan ke supermarket lokal seperti Superindo di berbagai kota yaitu Jogjayakarta, Solo, Semarang, Bogor, dan Salatiga. Pendistribusian produknya menggunakan para saluran distributor untuk dapat sampai ke tangan konsumen. Berbagai kerjasama telah digeluti oleh kelompok tani Tranggulasi baik dari sekolah, kampus, swasta, dan jajaran pemerintah sehingga memberikan dampak 
yang positif dalam pemasaran sayur organik yang dibudidayakan.

\section{Dampak Covid-19 terhadap Manajemen Sayur Organik "Tranggulasi" \\ Manajemen pemasaran merupakan} usaha yang dilakukan dalam merencanakan, mengimplementasikan, serta mengawasi kegiatan pemasaran agar tujuan dapat tercapai secara efektif dan efisien. Permasalahan yang terjadi saat pandemi Covid-19 yaitu pada distribusi hanya di beberapa daerah saja yang dapat di supply akibat adaya pembatasan akses keluar masuk di beberapa wilayah. "Kemarin waktu di Bogor nggak bisa karena nggak ada bis. Semarang juga terbatas. Kemudian yang bisa hanya yang dekat dan yang sudah langganan, kecuali yang langganan mesti bisa, seperti Superindo. Karena kita kan dituntut, kalau nggak supply kita kena kan",

Pengiriman barang tersebut dilakukan dengan cara mengantarkan produk sampai di depan portal pembatas, yang kemudian akan disalurkan kepada para penyalur mitranya untuk dipasarkan kembali. Selain itu pembelian tidak hanya dilakukan di tempat penjual (pasar modern), tetapi konsumen membeli sayur melalui media sosial WhatsApp. Semenjak adanya Covid19, permintaan secara online menjadi meningkat pesat dibandingkan sebelum maraknya Covid-19. "Semenjak ada covid ini banyakan yang laku itu online. Jadinya pada pesen ke rumah-rumah itu yang lebih laris, daripada kita jual di pasar. Lebih laku online nya karena mungkin ibu-ibu disana takut keluar, jadi yaudah telfon aja terus sayur datang."

Munculnya pandemi Covid-19 sekitar bulan Maret 2020 sempat membuat permintaan produk menjadi meningkat. Tempat-tempat yang mengalami kenaikan permintaan yaitu Superido wilayah Salatiga dan Semarang. Hal ini disebabkan karena banyak konsumen jarang berpergian seperti ke pasar lokal dan akhirnya lebih memilih untuk berbelanja di pasar modern. "Waktunya pada awal covid, kurang lebih satu bulan. Sekitar bulan Maret. Itu permintaan kami memang luar biasa. Meningkat sangat meningkatlah. Hampir lebih dari 100\%. Waktu itu istilahnya memang ada permintaan yang saya nggak pernah ada harus mengadakan. Contohnya seperti laos, jahe. Aneka jenis emponempon seperti itu."

Evaluasi dari Penerapan Bauran Pemasaran (Marketing Mix) Kelompok Tani Sayur Organik "Tranggulasi" di Masa Pandemi Covid-19

Evaluasi strategi pemasaran yang diterapkan oleh Tranggulasi didapatkan dari hasil wawancara. Wawancara tersebut dilakukan dengan pihak kelompok tani Tranggulasi. Bauran pemasaran dalam kelompok Tani Tranggulasi selama 
pandemi Covid-19 ini terbagi menjadi empat bagian yaitu:

\section{Produk}

Menurut Hartono dkk. (2012) sebuah produk menjadi sesuatu yang diasosiasikan oleh pelaku usaha kepada pasar. Dalam menyediakan kebutuhan sayur organik, para petani di Tranggulasi melakukan pola tanam tumpang sari. Namun apabila sayuran yang diminta konsumen ternyata tidak dibudidayakan oleh Tranggulasi, mereka akan tetap menyanggupi dengan cara membeli dari rekan mitra sesama petani sayur organik. Kualitas dari produk yang dihasilkan juga dipengaruhi oleh cuaca sebagai faktor utamanya. Jika di musim kemarau, rata-rata hasil panen sayuran organik bagus karena kebutuhan air yang masih dapat dicukupi oleh para petani, sedangkan di musim penghujan, rata-rata banyak sayuran yang busuk. Hal ini dikarenakan keadaan lingkungan yang terlalu lembab sehingga sayuran mudah rusak. "Produksi itu masalahnya cuma cuaca, jadi kalau ujan terus-menerus itu juga produksinya dikit. Tapi ada ujan, ada panas jadi bagus. Jadi tinggal sayurnya apa, komoditas nya apa. Misal spinach, itu kan harus kena air terus, tapi ga boleh kehujanan. Jadi cuma disiram, lembab aja dikit. Terus kalau kol kan harusnya kena hujan dikit. Apalagi brokoli, kalau panas kayak gini bagus."

Strategi penanganan yang dilakukan oleh petani adalah dengan membuat naungan seperti greenhouse dan membuat guludan yang cukup tinggi sekitar 20-25 cm di atas permukaan tanah agar tanah tidak tergenang air hujan. Produk dari Tranggulasi dipasarkan ke Superindo di kota Jogyakarta, Solo, Semarang, Bogor, dan Salatiga dengan berbagai label seperti: TOM (Tani Organik Merapi), SOM (Sayur Organik Merbabu), JTM (Jati Tani Makmur), Al-Barkah, OMAS FRESH (Organik Merbabu Asli), dan TOS (Tani Organik Serapin) agar dapat terserap banyak ke berbagai toko. Khusus untuk OMAS dipasarkan ke Bio Fresh Mart di Salatiga. Ada juga penjualan sayur organik dengan model curah, sehingga dikirim tanpa menggunakan merk dan dikemas dengan kardus. Standar mutu sayur rganik Tranggulasi dapat dilihat pada Tabel 1. 
Tabel 1. Standar Mutu Sayur Organik

\begin{tabular}{|c|c|c|}
\hline Komoditas & Kelas A & Kelas B \\
\hline Buncis & $\begin{array}{l}\text { Hijau tua, muda, } \\
\text { utuh, } \\
\text { mulus, tidak } \\
\text { busuk, tidak } \\
\text { lubang, tidak } \\
\text { luka, tidak ada } \\
\text { noda getah, } \\
\text { ukuran merata, } \\
\text { panjang } 13 \mathrm{~cm} .\end{array}$ & $\begin{array}{l}\text { Hijau tua, } \\
\text { mulus, bulat, } \\
\text { tidak luka, } \\
\text { tidak lubang, } \\
\text { tidak ada noda } \\
\text { getah, panjang } \\
14-15 \mathrm{~cm}\end{array}$ \\
\hline Labu Siam & $\begin{array}{lr}\begin{array}{l}\text { Mulus, } \\
\text { lubang, }\end{array} & \text { tidak } \\
\text { busuk, } & \text { tidak } \\
\text { kemasaran } & \end{array}$ & $\begin{array}{l}\text { Mulus, tidak } \\
\text { lubang, tidak } \\
\text { busuk, } \\
\text { 350g/kemasan }\end{array}$ \\
\hline Wortel & $\begin{array}{l}\text { Mulus, } \\
\text { cacat, } \\
\text { lurus, } \\
\text { lubang, } \\
\begin{array}{l}\text { lidak } \\
15 \mathrm{~cm}\end{array}\end{array}$ & $\begin{array}{l}\text { Mulus, tidak } \\
\text { beraturan, } \\
\text { lurus, panjang } \\
16-17 \mathrm{~cm}\end{array}$ \\
\hline
\end{tabular}

Sumber: Analisis Data Primer (2020)

Sayuran organik yang dibudidayakan oleh kelompk tani Tranggulasi didasarkan pada kebiasaan-kebiasaan permintaan konsumen di waktu-waktu tertentu yang telah diamati oleh para petani selama bertahun-tahun. Petani lebih menggunakan feeling untuk memperkirakan permintaan sayuran yang sesuai. "Jadi yang kami gunakan itu feeling, bulan ini penyerapannya bagus, bulan ini kurang. Jadi aku berani menganjurkan nanem banyak di bulan-bulan seperti ini, kalau bulan-bulan ini terbatas aja karena kalau di musim kemarau seperti ini mudah tanamannya. Terus mungkin panennya banyak bisa melimpah, itu saya batesin karena pasti bisa panen semua. Kalau musim penghujan bisa 3x lipat utk menutupi pesanan itu. Misal kalau musim kemarau, brokoli berani 1000 batang, tapi kalau misal musim penghujan, bisa sampai $3 x$ lipat karena banyak yang busuk."

Produksi sebelum dan selama pandemi cenderung tetap di kelompok tani tersebut. Pak Pitoyo mengungkapkan bahwa produksi yang dihasilkan tetap, namun hanya penyerapan di pasar modern yang berkurang, kemudian dialihkan ke pasar lokal. Selain itu peningkatan penjualan hanya terjadi di awal-awal maraknya Covid-19 saja. Pak Wahab dan Pak Harto turut mempertegas pernyataan Pak Pitoyo bahwa di saat awal pandemi, permintaan melonjak sangat tinggi namun setelah itu kembali stabil seperti saat sebelum adanya pandemi Covid-19.

Pembeda dari produk sayur organik Tranggulasi dengan yang lainnya adalah adanya logo organik Indonesia beserta nomor registrasi SNI (No.214/LSO-003IDN/10/16). Produk sayuran Tranggulasi telah dijamin oleh LSPO (Lembaga Sertifikasi Produk Organik) yang telah teregistrasi di dalamnya.

\section{Harga}

Harga suatu produk merupakan suatu aspek yang akan memberikan pemasukan bagi suatu usaha. Penetapan harga dalam penjualan sayur organik Tranggulasi adalah menghitung harga pokok penjualan (HPP) dari biaya permodalan seperti pupuk, bibit, 
tenaga kerja, pengolahan lahan, pengemasan, pelabelan, pengiriman, perpajakan, dan menyesuaikan harga yang sedang beredar di pasaran. "Perhitungan dari produksi, mulai permodalan seperti input nya sampai proses pendistribusian karena kan perlu ongkos-ongkos untuk packing maupun pengiriman. Ada juga ongkos perpajakan."

Apabila harga di pasaran mengalami penurunan harga, harga sayur Tranggulasi akan tetap. Jika harga pasaran naik, maka Tranggulasi akan ikut menaikkan harga. Tranggulasi tidak memberikan potongan harga terhadap para penyalur. Penjualan dilakukan sesuai perjanjian yang dilakukan di awal dengan kedua belah pihak saling menyetujui dengan harga yang telah ditetapkan. Tranggulasi memperbaharui harga setiap setengah bulan sekali, sedangkan bendera lain setiap seminggu sekali. "Mau harga di pasar itu jelek pun kita kan udah punya range, dan kebetulan untuk harga di kita itu masih di atas meskipun sejatuh-jatuhnya pasar. Organik itu sebetulnya ndak mahal pun kita untung karena kita nggak perlu pupuk, pupuk bikin sendiri, seandainya kita hargai pun itu murah. Terus pestisida, kita nggak beli mahal karna bikin sendiri. Misal beli pun kan juga murah."

Penetapan harga dari Tranggulasi yaitu dengan menetapkan harga tertinggi (titik aman)-namun tetap dapat diterima oleh para konsumen. Sayur organik tersebut dimasukkan ke Superindo dengan target pasar menengah ke atas. Sayuran organik yang tidak sesuai standar dan tidak dapat masuk ke pasar modern akan dijual ke pasar lokal dengan harga yang lebih rendah agar dapat terserap semua.

\section{Distribusi}

Distribusi merupakan kegiatan penyaluran suatu produk dari tangan produsen ke tangan konsumen. Sayuran organik Tranggulasi dipasarkan di pasar modern dan pasar lokal. Pasar modern yaitu Superindo di Jogyakarta, Solo, Semarang, Bogor, dan Salatiga. Pendistribusian sayur organik ke pasar lokal dibantu para mitra Tranggulasi khususnya untuk sayuran yang tidak memenuhi standar di pasar modern. "Kami kalau hanya mengandalkan satu merk saja tidak bisa terserap. Kami ada menggunakan merk TOM, SOM, JTM, AlBarokah, OMASH FRESH, dan TOS. Jadi sebagian produk yang dijualkan dari sini. Jadi semua merk ini masuk ke Superindo, kecuali yang OMASH FRESH itu di Bio Fresh Mart Salatiga. Superindo di Semarang ada 16, Jogja ada 9, Solo ada 4, Salatiga 1. Lainnya konsumen langsung melakukan pemesanan melalui whastapp (online)." 
Alat transportasi yang digunakan dalam pengiriman barang yaitu dengan mobil box pendingin dan ada juga beberapa penyalur yang datang untuk mengambil stok sayuran tersebut. Sistem pendistribusian sayuran organik Tranggulasi yaitu dengan sistem PO (Purcache Order) sesuai dengan kesepakatan di awal. Beberapa pengiriman dilakukan setiap hari (PO harian), ada juga yang hanya 2-3 kali seminggu. Kendala yang dihadapi saat munculnya pandemi Covid-19 adalah sulitnya melakukan pengiriman ke lokasi toko. Para mitra pun kesulitan untuk datang mengambil langsung di gudang Tranggulasi. Adanya pembatasan jalan dan akses keluar masuk daerah yang terbatas membuat proses pendistribusian menjadi terhambat, namun setelah munculnya adaptasi kebiasaan baru, pengiriman mulai berjalan lagi.

Masyarakat mulai berhati-hati dalam berpergian terutama menentukan tempat untuk berbelanja sayuran. Hal ini dapat dilihat dari meningkatnya nilai permintaan dan penjualan sayuran organik Tranggulasi ke Superindo. Pada saat awal pandemi covid, permintaan melonjak tinggi karena konsumen cenderung mengurangi belanja ke pasar tradisional untuk menghindari kontak fisik. "Waktunya pada awal covid, kurang lebih satu bulan. Sekitar bulan
Maret. Itu permintaan kami memang luar biasa. Meningkat sangat meningkatlah. Hampir lebih dari 100\%. Waktu itu istilahnya memang ada permintaan yang saya nggak pernah ada harus mengadakan. Contohnya seperti laos, jahe. Aneka jenis empon-empon seperti itu."

\section{Promosi}

Promosi berguna untuk mengenalkan produk atau jasa yang akan ditawarkan kepada konsumen. Selama pandemi Covid19 ini, promosi dilakukan dengan dua cara yaitu dengan media sosial dan tamu-tamu yang datang berkunjung. Media sosial tersebut diantaranya: WhatsApp (WA), Instagram, dan website (http://www.tranggulasi.com/) milik kelompok tani Tranggulasi. "Kalau untuk promosi, kami nggak promosi sendiri. Aku nggak terjun keluar sendiri. Terkadang seperti temen-temen njenengan, tamu-tamu pendatang dari instansi, kelompok tani, pengunjung wisata. Jadi nggak pakai media saya, yang bikin media itu temen-temen saya. Dibantu sama mereka."

Promosi sayur organik lebih digencarkan dengan menggunakan media sosial kepada para komunitas sesama petani sayur organik dan mitra dari Tranggulasi sendiri. Kekurangan dari promosi melalui website adalah hanya ketua saja yang dapat mengakses dan mengelola website tersebut, 
sehingga para anggota tidak bisa turut ikut campur dalam akses website milik Tranggulasi.

Tranggulasi sudah tidak melakukan pameran-pameran seperti dulu lagi namun dengan memanfaatkan orang-orang yang berkunjung kesana. Contohnya seperti mahasiswa yang sedang melakukan penelitian, tamu pendatang, dan instansi lain yang datang dengan berbagai kegiatan, sehingga promosi secara tidak langsung dilakukan dari mulut ke mulut para pengunjung.

Penerapan Analytical Hierarchy Process (AHP) pada Strategi Pemasaran Kelompok Tani Sayur Organik "Tranggulasi" dalam Adaptasi Kebiasaan Baru

AHP menurut Sewaka dan Muhammad (2016) adalah metode dengan menggunakan model hirarki yang terdiri dari tujuan, kriteria (dan beberapa sub kriteria) maupun alternatif untuk masingmasing permasalahan atau keputusan.

Perumusan Faktor, Aktor, Tujuan, dan Alternatif Strategi Pemasaran Tranggulasi

Pada penelitian ini, alat analisis AHP digunakan untuk mengetahui tingkat prioritas strategi pemasaran yang telah diperoleh dari hasil evaluasi strategi pemasaran sebelumnya. Berikut perumusan hirarki dari faktor, aktor, tujuan, dan alternatif.
1. Faktor

Pada alat analisis AHP ini, faktor-faktor yang digunakan dalam penentuan prioritas strategi pemasaran di Tranggulasi adalah bauran pemasaran (marketing mix) 4P yaitu harga, produk, promosi, dan distribusi.

2. Aktor

Aktor yang berperan dalam strategi pemasaran sayur organik di Tranggulasi adalah ketua, sekretaris, dan bendahara dalam kelompok tani Tranggulasi.

3. Tujuan

Tujuan yang ingin dicapai oleh Tranggulasi dalam menerapkan bauran pemasaran sayur organik.

a) Meningkatkan mutu dan kualitas

b) Menyesuaikan harga

c) Meningkatkan penjualan dan mengenalkan produk kepada konsumen

d) Mempermudah penyaluran produk ke tangan konsumen

4. Alternatif

Alternatif bagi pengembangan Tranggulasi antara lain:

a) Menyesuaikan pesanan produk dengan standar kualitas pasar

b) Survey perkembangan harga terbaru di pasaran 
c) Menyebarkan informasi produk melalui media sosial

d) Pemasaran dengan mitra melalui berbagai saluran distribusi

Struktur Hirarki Prioritas Strategi Pemasaran Kelompok Tani Tranggulasi dapat dilihat pada Gambar 1.

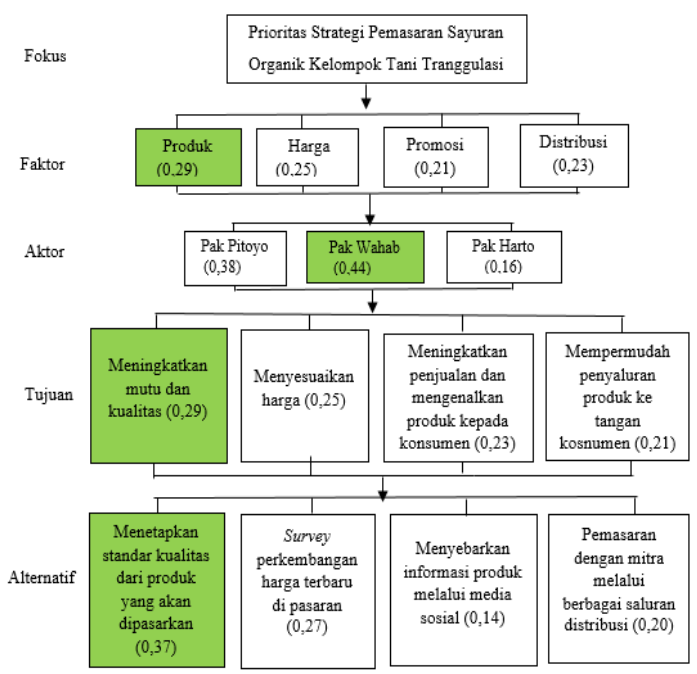

Gambar 1. Struktur Hirarki Prioritas Strategi Pemasaran Kelompok Tani Tranggulasi Analisis AHP

\section{Analisis Pemilihan Prioritas Strategi Pemasaran Tranggulasi}

Pemilihan prioritas strategi pemasaran Tranggulasi dilakukan setelah pengisian kuesioner matriks perbandingan oleh empat respoden dari anggota kelompok tani Tranggulasi. Pengolahan data terdiri dari lima tingkat hirarki yang akan dilakukan penilaikan indeks konsistensi.

\section{Tingkat Faktor Prioritas}

Faktor-faktor yang digunakan dalam menyusun strategi pemasaran yang ada di Tranggulasi terdiri dari empat unsur yaitu produk, harga, promosi, dan distribusi. Bobot dan Prioritas Faktor Bauran Pemasaran di Tranggulasi dapat dilihat pada Tabel 2.

Tabel 2. Bobot dan Prioritas Faktor Bauran Pemasaran di Tranggulasi

\begin{tabular}{lcc}
\hline \multicolumn{1}{c}{ Faktor } & Bobot & Prioritas \\
\hline Produk & 0,29 & 1 \\
Harga & 0,25 & 2 \\
Promosi & 0,21 & 4 \\
Distribusi & 0,23 & 3 \\
\hline
\end{tabular}

Sumber: Analisis Data Primer (2020)

Prioritas utama dalam strategi pemasaran di kelompok tani Tranggulasi adalah faktor produk dengan bobot 0,29. Retnoningsih (2016) menyatakan bahwa variasi produk dan kemasan merupakan poin penting karena dapat menambah nilai produk yang akan dipasarkan kepada konsumen. Produk dengan mutu dan kualitas yang tinggi merupakan hal terpenting bagi kelompok tani Tranggulasi. Semua sayur yang dijual sudah melewati tahap sortasi dan grading oleh kelompok tani Tranggulasi.

Prioritas kedua adalah faktor harga dengan bobot 0,25 . Tranggulasi juga sangat memperhatikan harga penjualan sayur organiknya. Harga dihitung dari harga pokok penjualan mulai dari biaya pupuk, tenaga kerja, bibit, dan modal. Setelah itu Tranggulasi memasang harga dengan biaya tertinggi sehingga tidak akan rugi. Diikuti 
oleh faktor distribusi dengan prioritas ketiga yaitu dengan bobot 0,23 . Distribusi merupakan faktor penting dalam penyaluran sayur organik hingga ke tangan konsumen. Penjualan sayur organik Tranggulasi semuanya dikirimkan dengan menggunakan perantara atau saluran distribusi. Prioritas terakhir dalam bauran pemasaran yang diterapkan oleh kelompok tani Tranggulasi yaitu promosi dengan bobot 0,21. Promosi yang dilakukan oleh Tranggulasi sekarang adalah dengan media sosial seperti website milik Tranggulasi dan WhatsApp (WA).

\section{Tingkat Aktor Prioritas}

Pada dasarnya semua orang dalam kelompok tani Tranggulasi memiliki pengaruh terhadap pemasaran sayur organik. Namun hanya beberapa orang saja yang mempunyai wewenang dalam mengambil keputusan yang ada di Tranggulasi. Dari ketiga aktor tersebut, didapatkan nilai bobot dan prioritas dalam pengambilan keputusan dan perannya dalam strategi pemasaran. Bobot dan Prioritas Aktor Bauran Pemasaran di Tranggulasi dapat dilihat pada Tabel 3.

Tabel 3. Bobot dan Prioritas Aktor Bauran Pemasaran di Tranggulasi

\begin{tabular}{lcc}
\hline \multicolumn{1}{c}{ Aktor } & Bobot & Prioritas \\
\hline Ketua & 0,38 & 2 \\
Sekretaris & 0,44 & 1 \\
Bendahara & 0,16 & 3 \\
\hline
\end{tabular}

Sumber: Analisis Data Primer (2020)
Aktor yang memiliki pengaruh paling besar dalam strategi pemasaran adalah sekretaris dengan bobot 0,44. Sekretaris memilki peran sebagai bagian pengadaan barang sayur organik yang akan di supply ke berbagai pasar. Aktor yang memiliki pengaruh besar kedua adalah ketua dengan bobot 0,38. Selaku ketua bertugas untuk mengawasi keberlangsungan kelompok tani dan jalannya proses pemasaran. Aktor selanjutnya yaitu bendahara yang berperan dalam pemasaran di Tranggulasi dengan bobot 0,16 . Bendahara merupakan orang yang bertanggungjawab atas pemasukan dan pengeluaran yang dilakukan oleh Tranggulasi. Bendahara berwenang dalam membayarkan dana atas sayur organik milik anggota tani lainnya yang telah terjual.

\section{Tingkat Tujuan Prioritas}

Pada hasil pengolahan data yang dilakukan dengan AHP diperoleh bobot dan prioritas terhadap ke empat tujuan tersebut. Bobot dan prioritas tujuan strategi pemasaran Tranggulasi dapat diihat pada Tabel 4. 
Tabel 4. Bobot dan Prioritas Tujuan Bauran Pemasaran di Tranggulasi

\begin{tabular}{lcc}
\hline \multicolumn{1}{c}{ Alternatif } & $\begin{array}{c}\text { Bobo } \\
\mathrm{t}\end{array}$ & $\begin{array}{c}\text { Priorita } \\
\mathrm{s}\end{array}$ \\
\hline $\begin{array}{l}\text { Menetapkan standar } \\
\text { kualitas dari produk yang } \\
\text { akan dipasarkan }\end{array}$ & 0,37 & 1 \\
\hline $\begin{array}{l}\text { Survey perkembangan } \\
\text { harga terbaru dipasaran }\end{array}$ & 0,27 & 2 \\
\hline $\begin{array}{l}\text { Menyebarkan informasi } \\
\text { produk melalui media } \\
\text { sosial } 0,14\end{array}$ & 4 \\
$\begin{array}{l}\text { Pemasaran dengan mitra } \\
\text { melalui berbagai saluran } \\
\text { distribusi }\end{array}$ & 0,20 & 3 \\
\hline
\end{tabular}

Sumber: Analisis Data Primer (2020)

Berdasarkan tabel diatas, tujuan utama yang ingin dicapai dalam melakukan strategi pemasaran adalah meningkatkan mutu dan kualitas sayur organik. Semua sayur dipanen menyesuaikan kriteria dan standar yang telah ditentukan. Dalam setiap proses budidaya, para petani selalu berusaha untuk menjaga mutu dan kualitas sayur organik agar dapat diterima baik dan memuaskan konsumen. Prioritas tujuan yang kedua adalah menyesuaikan harga. Penyesuaian harga perlu dilakukan sebagai ajang promosi dari Tranggulasi.

Oleh karena itu Tranggulasi selalu melakukan survey harga seminggu sekali, dimana informasi tersebut didapat dari rekan-rekan kerja dan mitra bisnis. Selanjutnya, prioritas tujuan yang ketiga adalah mengenalkan produk kepada konsumen. Tujuan ini dapat tercapai salah satunya selaras dengan penyesuaian harga yang dilakukan pihak Tranggulasi. Selain itu pengenalan produk yang dilakukan selama pandemi ini adalah melalui mitramitra dan rekanan yang turut membantu menyebarkan produk jualan milik Tranggulasi. Prioritas tujuan yang terakhir adalah mempermudah penyaluran produk ke tangan konsumen. Tujuan ini juga penting karena Tranggulasi menggunakan berbagai macam bendera selain milik Tranggulasi untuk dapat menyebarkan sayur organiknya ke banyak konsumen.

4. Tingkat Alternatif Prioritas

Adanya alternatif strategi yang dilakukan dalam mencapai tujuan-tujuan yang ingin dicapai oleh Tranggulasi. Oleh karena itu dengan adanya analisis AHP ini, didapatkan bobot dan prioritas alternatif strategi pemasarannya. Bobot dan Prioritas Faktor Bauran Pemasaran di Tranggulasi dapat dilihat pada Tabel 5.

Tabel 5. Bobot dan Prioritas Faktor Bauran Pemasaran di Tranggulasi

\begin{tabular}{lcc}
\hline \multicolumn{1}{c}{ Tujuan } & Bobot & Prioritas \\
\hline $\begin{array}{l}\text { Meningkatkan mutu } \\
\text { dan kualitas }\end{array}$ & 0,29 & 1 \\
$\begin{array}{l}\text { Menyesuaikan harga } \\
\text { Meningkatkan }\end{array}$ & 0,25 & 2 \\
$\begin{array}{l}\text { penjualan dan } \\
\text { Mengenalkan produk }\end{array}$ & 0,23 & 3 \\
$\begin{array}{l}\text { kepada konsumen } \\
\text { Mempermudah } \\
\text { penyaluran produk } \\
\text { ke tangan konsumen }\end{array}$ & 0,21 & 4 \\
\hline
\end{tabular}

Sumber: Analisis Data Primer (2020) 
Berdasarkan Tabel 5 bobot dan prioritas terhadap alternatif strategi pemasaran yang paling besar adalah menetapkan standar kualitas dari produk yang akan dipasarkan. Agar menjaga kesesuaian produk sayuran dengan permintaan pasar, maka Tranggulasi menetapkan standar kualitas dari setiap sayuran. Semua sayur harus dilakukan pengecekan seperti sortasi dan grading sebelum dikirimkan ke pasar modern. Alternatif selanjutnya adalah survey perkembangan harga terbaru dipasaran. Untuk dapat bergerak dinamis, alternatif dengan survey harga perlu dilakukan paling tidak seminggu sekali untuk mengetahui harga yang beredar di pasaran. Kemudian strategi pemasaran yang dilakukan Tranggulasi adalah mengikuti tren pasar yang akan menarik perhatian konsumen apabila memang ada perubahan dan dirasa perlu.

Prioritas selanjutnya adalah pemasaran dengan mitra melalui berbagai saluran distribusi. Tranggulasi menggunakan berbagai saluran distribusi sebagai alternatif untuk menyalurkan produk dari produsen hingga ke tangan konsumen. Alternatif yang menjadi prioritas terakhir adalah menyebarkan informasi produk melalui media sosial. Tranggulasi sudah tidak pernah melakukan promosi dengan melakukan pameran. Oleh karena itu alternatif yang dijalankan sekarang yaitu dengan promosi melalui sosial media. Menyebarkan informasi terkait sayur organik yang dimiliki oleh Tranggulasi kepada rekan kerja, sesama petani, maupun di berbagai grup komunitas WhatsApp. Update di website milik Tranggulasi juga masih dilakukan oleh Pak Pitoyo.

\section{KESIMPULAN DAN SARAN}

Dampak Covid-19 terhadap manajemen di kelompok tani Tranggulasi adalah pendistribusian yang terhambat karena pembatasan wilayah yang menyulitkan dalam melakukan pengiriman sayur organik ke distributor. Pemesanan sayur lebih banyak dilakukan secara online melalui aplikasi karena pandemi Covid-19. Hasil evaluasi dari penerapan bauran pemasaran selama pandemi Covid-19 dari strategi produk yaitu peningkatan penjualan di awal maraknya pandemi Covid-19 di pasar modern karena konsumen menghindari pasar lokal. Tranggulasi tetap memperhatikan standar yang telah dibuat mulai dari pengolahan lahan hingga pelabelan. Strategi harga yang dijalankan oleh Tranggulasi adalah menetapkan harga jual sayur organik dengan menghitung HPP dari biaya permodalan dan menyesuaikan 
harga pasar. Strategi distribusi untuk Tranggulasi dilakukan melalui para distributor yang sudah bekerjasama dengan Tranggulasi. Strategi promosi dilakukan dengan meminta bantuan atau membagikan informasi kepada mitra kerja, teman-teman, dan komunitas sesama petani. Berdasarkan hasil analisis AHP, didapatkan faktor prioritas strategi pemasaran yang menjadi fokus pertama adalah produk dengan bobot sebesar 0,29. Di level aktor, adalah sekretaris dengan bobot sebesar 0,44. Pada level tujuan, tujuan dengan meningkatkan mutu dan kualitas dari hasil produk sayur organik yang diproduksi dan akan dipasarkan dicapai dengan bobot 0,29. Pada level alternatif, menetapkan standar kualitas produk yang akan dipasarkan merupakan prioritas utama dalam pendistribusiannya kepada para konsumen dengan bobot 0,37. Saran yang dapat diberikan berdasarkan penelitian yang telah dilakukan peneliti adalah kelompok tani Tranggulasi dapat meningkatkan strategi promosi seperti personal selling dengan cara menjualkan produknya sendiri ke pasar atau membuat pameran. Selain itu dapat bekerjasama dengan anggota kelompok tani lain dalam pengembangan ekonomi lokal di masa pandemi Covid-19 untuk memberikan kesejahteraan bagi para petani. Bagi peneliti selanjutnya, agar dapat difokuskan pada strategi promosi yang masih dapat dikembangkan dan diagali potensinya.

\section{DAFTAR PUSTAKA}

Abdalloh, Mildan. 2020. Pasar Sepi Akibat Corona, Petani Sayuran Manfaatkan Jualan Online. ayobandung.com/read/2020/03/26/8396 5/pasar-sepi-akibat-corona-petanisayuran-manfaatkan-jualan-online. Diakses 27 Mei 2020.

Hartono, H., Karyana H., Marshelia M. 2012. Pengaruh Strategi Pemasaran Terhadap Peningkatan Penjualan pada Perusahaan dengan Menetapkan Alumni dan Mahasiswa Universitas Bina Nusantara Sebagai Objek Penelitian. Binus Journal Publishing: Jurnal Manajemen, 2(3):882-897.

Kihi, Asrian Tini. 2014. Pelaksanaan Bauran Pemasaran Sayuran Organik Kelompok Tani Tranggulasi. Skripsi. Fakultas Pertanian dan Bisnis UKSW. Salatiga.

Mariana. 2020. Dampak Corona, Penjualan Sayur Organik Meningkat 50\%. https://banjarmasin.tribunnews.com/ 2020/04/15/dampak-coronapenjualan-sayur-organik-meningkat50-persen. Diakses 28 Mei 2020.

Putri, Budi Rahayu Tanama. 2017. Manajemen Pemasaran. Denpasar: Fakultas Peternakan Universitas Udayana.

Retnoningsih, Fitria, Iga Oka Suryawardani, dan Nyoman Parining. 2016. Pemilihan Prioritas Startegi Pemasaran Coklat Olahan Berdasarkan Metode Analytical Hierarchy Process (Studi Kasus di Perusahaan Magic Chocolate, Kabupaten Gianyar, Provinsi Bali). E-Jurnal Agribisnis dan Agrowisata, 5(1):7-8.

Sewaka dan Muhammad Yusuf. 2016. Menentukan Strategi Pemasaran Wafer Cokelat Menggunakan Metoda AHP Pada Perusahaan PT.XYZ Tangerang. Jurnal Ilmiah Ilmu Manajemen, 3(2): 44 -45 . 